\title{
RESEÑA DE SENTENCIAS DEL TRIBUNAL SUPREMO
}

\author{
Maria Rosario Alonso ibáñez \\ Seminario de Derecho administrativo. Universidad de Oviedo
}

\begin{abstract}
SUMARIO: I. FUENTES: 1. Disposiciones de carácter general.-ll. DERECHOS FUNDAMENTALES Y LIBERTADES PÚBLICAS: 1. Igualdad ante la Ley.-III. ACTO ADMINISTRATIVO: 1. Desviación de poder. 2. Actos discrecionales.-IV. Administración local: 1. Autonomía local. 2. Derecho al acceso a los cargos y funciones públicas. 3. Potestad autoorganizativa.-V. AdMINISTRACIÓN CORPORATIVA: 1. Naturaleza jurídica.-VI. HACIENDAS LOCALES: 1. Impuesto municipal sobre gastos suntuarios. 2. Impuesto sobre radicación.-VII. Contratos: 1. Actos separables. 2. Contrato de servicios.-VIII. ReSPONSABILIDAD PATRIMONIAL: 1. Nexo causal.-IX. EXPROPIACIÓN FORZOSA: 1. Jurado Provincial de Expropiación. 2. Expropiación en beneficio de Corporaciones locales.$X$. Dominio público: 1. Vía pecuaria. 2. Puerto deportivo.-XI. Servicio público: 1. Radiodifusión y televisión. 2. Energía eléctrica.-XII. RECURSOS ADMINISTRATIVOS: 1. Resoluciones tardías. -XIII. JuRISDICCION CONTEnCIOSO-AdMINISTRATIVA: 1. Actos impugnables. 2. Legitimación corporativa. 3. Legitimación por subrogación. 4. Recurso de apelación.-XIV. Funcionarios púBLICOS: 1. Incompatibilidades. 2. Excedencia. 3. Retribuciones del personal de Organismos Autónomos. 4. Retribuciones de catedráticos y profesores. 5. Diferencias retributivas. 6. Acceso.-XV. SANCIONES: 1. Expediente disciplinario. 2. Derecho administrativo sancionador. 3. Principio de legalidad. 4. Actividad administrativa sancionadora. 5. Contrabando.-XVI. URBANISMO: 1. Planeamiento. 2. Licencias. 3. Cesión gratuita. 4. Patrimonio Histórico.
\end{abstract}

\section{FUENTES}

1. ${ }^{\circ}$ Orden del Ministerio de Economía y Hacienda sobre cuantía de las retribuciones de los funcionarios públicos incluidos en el ámbito de aplicación de la Ley 30/1984, de 2 de agosto. No tiene el rango de Reglamento ejecutivo, por lo que no es exigible en su elaboración el Dictamen del Consejo de Estado

"Las entidades recurrentes pretenden, en primer lugar, que se declare la radical y total nulidad de la Orden ministerial de 2 de enero de 1985 sobre cuantía de las retribuciones de los funcionarios públicos incluidos en el ámbito de aplicación de la Ley $30 / 1984$, de 2 de agosto, sobre gastos de personal, con el fundamento de carácter de reglamento ejecutivo de la misma $y$ omisión del preceptivo informe del Consejo de Estado. Pero esa alegación no es admisible, pues si bien puede atribuirse a dicha Orden ministerial la calidad de disposición general normativa, tanto por reunir las notas de generalidad abstracción y carácter imperativo, que por sí solas no son suficientes definitorias de las normas 
en cuanto que también son propias de los actos aplicativos generales, como porque así se deduce del modo elegido por el autor de la Orden para comunicarla a sus destinatarios, que ha sido el de su publicación en el «BOE», precisamente en el apartado propio Disposiciones Generales y de forma articulada de su concepción; $y$, sobre todo, porque ello viene a desprenderse de su contenido material que constituye una regulación provisional del régimen retributivo de los funcionarios públicos, completando el ordenamiento jurídico durante el lapso temporal que transcurra hasta que el Gobierno cumpla el mandato legal contenido en el artículo 11, p. 4, de la Ley $30 / 1984$, respecto a la determinación del complemento específico, a pesar de ello no cabe atribuir a tal disposición general ministerial el carácter de reglamento ejecutivo, que es condición exigible conforme al artículo 22, p. 3, de la Ley Orgánica del Consejo de Estado, para que sea necesario el Dictamen de este Superior Organo Consultivo, en cuanto que falta la específica remisión legal que autorizará al Ministerio de Economía y Hacienda para el desarrollo ejecutorio de las Leyes 30/1984 y 50/1984, puesto que, por el contrario, la Orden ministerial impugnada aparece como una mera manifestación de la potestad reglamentaria independiente, atribuida al Ministerio de Economía y Hacienda, por el artículo 9, ap. c), e) y g) de la Ley General Presupuestaria de 1977 y artículo 5 de la Ley 30/1984, de reforma de la Función Pública, le faculta para dictar disposiciones generales en los ámbitos afectantes a la Hacienda Pública, ejecución de los Presupuestos generales y política financiera del Gobierno, y medidas relativas a personal que puedan suponer modificaciones del gasto, disposiciones que, en definitiva, vienen a ampliar la genérica potestad reglamentaria atribuida a ese Ministerio por el artículo 14, p. 3 de la Ley de Régimen Jurídico de la Administración del Estado, justificando su intervención en ámbitos materiales propios de otros Departamentos ministeriales. Por lo que no siendo un reglamento ejecutivo, no era exigible el dictamen del Consejo de Estado.» (Sentencia de 31 de enero de 1987. Sala 5. ${ }^{\circ}$, Cáncer Lalanne. Ar. 283.)

2. Orden del Ministerio de Sanidad y Consumo sobre regulación del régimen de jornada del Personal Facultativo de los Servicios Jerarquizados de las Instituciones Sanitarias de la Seguridad Social. Reglamento ejecutivo. Diferencia con los actos administrativos

«El examen de la aludida Orden ministerial pone de manifiesto. sin lugar a dudas, que estamos ante una disposición de carácter 
general $y$ no ante un acto administrativo -como sostiene el defensor de la Administración- porque constituye un "instrumento ordenador" que es lo que esencialmente distingue la disposición general del acto administrativo que viene configurado como algo "ya. ordenado" y limitado a ejecutar y a cumplir una "ordenación previa"; diferenciándose también el acto administrativo de la disposición general en que el primero con su cumplimiento se agota y para un nuevo cumplimiento se habrá de dictar un nuevo acto; en tanto que la disposición general o reglamento no se consume con cumplirlo una vez sino que sigue vigente y es susceptible de una pluralidad indefinida de cumplimientos.) (Sentencia de 19 de enero de 1987. Sala 4. ${ }^{\circ}$ Bruguera Manté. Ar. 431.)

\section{DERECHOS FUNDAMENTALES Y LIBERTADES PUBLICAS}

1. ${ }^{\circ}$ Igualdad ante la Ley. Supuesta vulneración del derecho. Integración en el INS de Catedráticos y Profesores que prestaban servicios en Hospitales Clínicos (Orden de 13 de septiembre de 1985)

«... y como ésta y no otra cuestión es, en síntesis, la cuestión planteada en el presente recurso por los Médicos y ATS demandantes y no se hace la comparación con los que se encuentran ligados por una misma situación profesional con otros Médicos que hayan sido declarados compatibles o indemnizados por la privación singular de otro puesto de trabajo, es claro, que la comparación no se produce en los mismos términos, no se puede deducir la infracción del principio de igualdad ante la Ley; lo que el artículo 14 prohíbe es que situaciones "idénticas" sean tratadas de forma diferente y la situación de los actores no es igual a la de los demás trabajadores por cuenta ajena, ya que ni se cita otro grupo de funcionarios que por una doble actividad profesional perciban por ello una mayor retribución, aparte que la pretensión de indemnización por el Estado no está incluida en los artículos protegidos por la Ley 62/1978, el principio de igualdad es cierto que vincula a todos los poderes públicos, incluido el legislativo, pero no prohíbe que el legislador o el ejecutivo contemple la necesidad o conveniencia de diferenciar situaciones distintas y darles un tratamiento diverso siempre que no vulneren otros principios constitucionales y que no vayan contra la esencia del derecho a la igualdad, el cual prohíbe toda desigualdad que por su alcance sea irrazonable y por 
ello haya de calificarse de discriminatorio -sentencias del Tribunal Constitucional de 2 de julio y 19 de octubre de 1981 y 21 de julio de 1983-; pero no impide que en función de las circunstancias concurrentes, en cada caso, situaciones distintas, produzca una diferenciación de tratamiento, prohíbe la discriminación pero no la diferenciación entre situaciones objetivas distintas, sino que, ante situaciones iguales deben darse tratamientos iguales.) (Sentencia de 19 de enero de 1987. Sala 3. ${ }^{a}$ Roldán Martínez, Ar. 11.)

\section{ACTO ADMINISTRATIVO}

\section{Desviación de poder}

"La desviación de poder, a la que se refieren el artículo 106.1 de la Primera Ley del Estado, y los artículos 40 y 48 de la Ley de Procedimiento Administrativo, está definida por el artículo 83.3 de la Ley de la Jurisdicción y ha sido matizada por la jurisprudencia, exigiéndose para su concurrencia: a) Un acto, aparentemente ajustado a la legalidad pero que en el fondo persigue un fin distinto al interés público querido por el legislador; b) Presunción de que la Administración ejerce sus facultades conforme a Derecho, y c) No poder exigirse una prueba plena sobre su existencia, ni tampoco poder fundarse en meras presunciones o conjeturas, siendo necesario acreditar hechos o elementos suficientes para formar en el Tribunal la convicción de que la Administración acomodó su actuación a la legalidad, pero con finalidad distinta a pretendida por la norma.» (Sentencia de 10 de febrero de 1987. Sala 5. ${ }^{a}$ Hernando Santiago. Ar. 582.)

2. Control jurisdiccional de los actos discrecionales. Aplicación de esta doctrina a la potestad de planeamiento

«El genio expansivo del Estado de Derecho ha determinado el alumbramiento de técnicas que permiten que el control jurisdiccional, tan ampliamente dibujado por el artículo 106.1 de la Constitución, se extienda incluso a los aspectos discrecionales de las potestades administrativas.

Nuestra jurisprudencia ha acogido los logros doctrinales producidos al respecto, aplicándolos reiteradamente:

A) En primer lugar, a través del control de los hechos determinantes, que en su existencia y características escapan a toda discrecionalidad: los hechos son tal y como la realidad los 
exterioriza. No le es dado a la Administración inventarlos o desfigurarlos aunque tenga facultades discrecionales para su valoración.

B) $Y$, en segundo lugar, mediante la contemplación o enjuiciamiento de la actividad discrecional a la luz de los principios generales del Derecho -art. $1 .^{\circ}, 4$, del Código civil-, que al informar todo el ordenamiento jurídico -son la atmósfera en la que respiramos jurídicamente-, y por tanto también la norma habilitante que atribuye la potestad discrecional, imponen que la actuación de ésta se ajuste a las exigencias de dichos principios -la Administración no está sometida sólo a la ley sino también al Derecho, artículo 103. 1 de la Constitución.

Esta doctrina es plenamente aplicable a los aspectos discrecionales, tan importantes, de la potestad de planeamiento. Por tanto, la precisión jurisdiccional se extenderá, en primer lugar, a la verificación de la realidad de los hechos, para, en segundo término, valorar si la decisión planificadora discrecional guarda coherencia lógica con aquéllos, de suerte que cuando sea clara la incongruencia o discordancia de la solución elegida con la realidad que es su presupuesto inexorable, tal decisión resultará viciada por infringir el ordenamiento jurídico y más concretamente el principio de interdicción de la arbitrariedad de los poderes públicos...) (Sentencia de 1 de diciembre de 1986. Sala 4. ${ }^{a}$ Delgado Barrio. Ar. 417.)

\section{ADMINISTRACION LOCAL}

1. Autonomía Local. Impugnación de acuerdos de las Corporaciones locales por control de legalidad sobre ejercicios de competencias del sistema retributivo de funcionarios de Entes locales

«La Autonomía garantizada por la Constitución a los municipios -arts. 137 y 140- hace referencia a un poder limitado, es decir, perfilado por las leyes a dictar por el Estado -art. 149.1.18 de la Constitución-e incluso, en su caso, por las Comunidades Autónomas, cuando éstas hayan asumido competencias al respecto -carácter bifronte del régimen jurídico de los Entes locales-, leyes, las mencionadas, que han de respetar siempre el reducto indisponible o núcleo esencial de la autonomía, a concretar de acuerdo con la conciencia social de cada tiempo y lugar.") (Sentencia de 17 de noviembre de 1986. Sala 4. ${ }^{\circ}$ Delgado Barrio. Ar. 407.) 
2. Acuerdo de censura de un Diputado por parte de la Corporación Provincial de Jaén en "todos» sus cargos de representación orgánica. Comisiones Informativas. El derecho al acceso a los cargos y funciones públicas implica también el de mantenerse en ellos

«... a) Siguiendo la doctrina sentada por el Tribunal Constitucional en sentencia de 6 de marzo de 1985, entendemos que las Comisiones Informativas son órganos sólo en sentido impropio y en realidad meras divisiones internas del Pleno Provincial, carentes de competencias decisorias propias, y cuya función se reduce a preparar las decisiones de aquél, estudiando e informando previamente los asuntos sobre los que debe resolver, y en cuanto parte del pleno, debe reproducir en lo posible la estructura política de éste aunque no haya ningún precepto en la Constitución ni en la legislación que establezca cuál haya de ser su composición, pues de otro modo se eliminaría toda participación de los miembros de la minoría en un estado importante del proceso de decisión y se hurtaria la posibilidad de participar con plena eficacia en el estudio final de la decisión. b) El derecho a acceder a los cargos y funciones públicas, reconocido en el artículo 23.2 de la Constitución implica también el de mantenerse en ellos y desempeñarlos en términos tales que no se vacíe de contenido la función que ha de desempeñar, se le estorbe o dificulte, o se coloque en condiciones inferiores a otras, pues a todos se han de conceder iguales condiciones de acceso al conocimiento de los asuntos y de participación en los distintos estudios del proceso de decisión. c) En atención a lo anteriormente expresado, no cabe que a un Diputado se le haga cesar en "todos" sus cargos de representación orgánica, cual con detalle $y$ acierto se expresa en la sentencia apelada, por unas manifestaciones declaradas irrelevantes penalmente por la jurisdicción competente, sin perjuicio de la viabilidad de censura y descalificación política por la Corporación Provincial, pues aquel cese total si bien no impide al Diputado de hacerse oír en la decisión final sí le priva de toda posibilidad de participación en los diferentes estudios del proceso de decisión, lo que supone ser sometido en el ejercicio de su función representativa a unas condiciones o limitaciones que lesionan su derecho fundamental de mantenerse y desempeñar su cargo representativo en igualdad con los demás miembros de la Diputación, y se vulnera el artículo 23.2 de la Constitución.» (Sentencia de 16 de marzo de 1987. Sala 3. ${ }^{a}$ Fernández Santamaría. Ar. 7.) 
3. Potestad autoorganizativa municipal. Modificación de horarios de trabajo y supresión de retribución complementaria por Corporación local. Exclusión Ley 62/1978

«En relación con los acuerdos municipales que establecieron un cierto horario en las oficinas municipales y suprimieron una retribución complementaria, ambos deben de ser encuadrados, como bien hace la sentencia apelada, en el marco de la potestad autoorganizativa municipal, y si los funcionarios se muestran disconformes con tal actuación municipal, el recurso contencioso-administrativo ordinario es el procedente para dirimir la conformidad jurídica de tales decisiones municipales, en este sentido, la sentencia de esta Sala de 7 de abril de 1986 ha venido a establecer que las discrepancias entre el funcionario y la organización administrativa a la que pertenece, con base en la relación de servicio, quedan excluidas del procedimiento preferente y sumario de la Ley 62/1978.") (Sentencia de 20 de enero de 1987. Sala 3. ${ }^{a}$ Ruiz-Jarabo Ferrán. Ar. 19.)

\section{ADMINISTRACION CORPORATIVA}

1. Naturaleza del Instituto de Censores Jurados de Cuentas. Colegio Profesional. Estatutos. Diferenciación de los Titulares Mercantiles. Sociedades de auditoría

«... En realidad no se trata de materia atribuida por esta vía a este tribunal el proferir una declaración que, poniendo fin a tan dispares y a veces vacilantes criterios, califique al Instituto como colegio profesional o no, mas será necesario alguna reflesión sobre este punto, por las consecuencias que de ello haya que lograr para lo que verdaderamente es competencia y deber de este tribunal, que no es otra cosa que pronunciarse sobre si el Real Decreto $2777 / 1982$, de 24 de septiembre, por el que se aprueban los Estatutos de aquel Instituto, se ajusta o no al ordenamiento jurídico aplicable. Con esa finalidad, y con la aludida limitación, conviene decir, atendida la regulación que de los colegios profesionales se hace en la Ley de 13 de febrero de 1974, con las modificaciones introducidas por la de 26 de diciembre de 1978, que si los mismos tienen como fin esencial la ordenación del ejercicio de las profesiones, la representación exclusiva de las mismas y la defensa de los intereses profesionales de los colegiados, sin necesidad de desa- 
tender a más pormenorizaciones de lo que incluye aquel texto legal, parangonándolo todo ello con lo que incluyen los Estatutos del Instituto de Censores Jurados de Cuentas, no hay que esforzarse mucho para advertir que la naturaleza, fines y organización de éste vienen a ser coincidentes con los que caracterizan a los colegios profesionales, y siendo ello así, y a los limitados efectos a que repetidamente hemos aludido, habrá que concluir que deberán ponderarse las exigencias legales demandadas respecto de los colegios profesionales y su reservancia o desconocimiento, exigencias calificables como máximas o superiores supuestamente a la declaración de licitud del Real Decreto recurrido.

... No parece, pues, desacertado afirmar que tras la sentencia de 30 de diciembre de 1981 (R. 4.825), que proclamó el ajuste a Derecho del Real Decreto de 1979 que desinaló por entero al Instituto del Consejo Superior de Titulares Mercantiles, sostener que aquél no es más que un órgano de éste, no es otra cosa que pretender resucitar una cuestión que -lo hemos expuesto ya- está fenecida por virtud de la eficacia y alcance que debe reconocerse a los pronunciamientos judiciales que ganaron la autoridad de la cosa juzgada.

... Posiblemente convenga compendiar cuál es el sentido de los razonamientos que anteceden, reiterando que según el criterio de la Sala, el Instituto de Censores Jurados de Cuentas de España ha sido y es algo más que un simple órgano del Consejo Superior de Colegios de Titulares Mercantiles, por disponer de órganos, competencia profesional, atribuciones y finalidades propias, que pasó a depender del Consejo, mas sin perder nunca una personalidad de la que era titular, dependencia que cesó por virtud del Real Decreto de 1979, sin la que la aprobación de sus Estatutos, mediante el Real Decreto de 1982, desvirtúe las posibilidades legales permitidas.

... En cuanto a las sociedades de auditoría, la parte recurrente observa su ilicitud desde el punto en que los Estatutos las vienen a tratar como "profesionales", siendo que se requiere la colegiación, y la titulación, lo que está reservado a las personas físicas; aparte invadir ámbitos competenciales ajenos. Admite la propia parte recurrente que los profesionales pueden llegar a fórmulas de comunidad de interés sociedades o colectivas, mediante el establecimiento de las correspondientes relaciones internas, pero sin que se puedan elevar a la categoría de entidades profesionales como sujetos per se del ejercicio de tal actividad. Mas lo que en este punto se advierte no es otra cosa que la ausencia de una verdadera y directa prohibición legal, y la aceptación de una tendencia que cabe calificar como de ya arraigada en otros medios nacionales 
ajenos al nuestro, incluso en la Comunidad Económica Europea, aparte de que es necesario destacar cómo en el ordenamiento que sobre la materia incluyen los Estatutos impugnados se circunscribe la posibilidad de integración en esas sociedades de auditoría a los miembros numerarios del Instituto de Censores Jurados de Cuentas, sin más objeto que el que es propio de los mismos bajo la responsabilidad de éstos, afectadas a las incompatibilidades de miembros, y siendo los dictámenes suscritos necesariamente por uno de los socios." (Sentencia de 27 de enero de 1987. Sala 3. Roldán Martínez. Ar. 220.)

\section{HACIENDAS LOCALES}

1. Impuesto municipal sobre gastos suntuarios. Aplicación a tablaos de flamenco

«A mayor abundamiento, esta Sala ha tenido ocasión de pronunciarse en torno a la cuestión que plantea el apelante en su sentencia de 21 de octubre de 1985, donde se establece la doctrina de que no puede hablarse de infracción del artículo 24 de la Ley General Tributaria ni puede entenderse extendido el hecho imponible más allá de sus términos estrictos, puesto que lo que las dos normas con rango de Ley gravan (Ley de Bases del Régimen Local y Real Decreto-ley de 20 de julio de 1979) no son unos establecimientos concretos y determinados, sino todos aquellos locales destinados a esparcimiento, de entre los cuales el legislador mencionó unos muy concretos, y acudió, respecto a los demás, a sus características o a su finalidad -el esparcimiento-, debiendo relacionarse esta circunstancia con el fin perseguido con el Impuesto, que es el de gravar a todos aquellos que demuestran una mayor capacidad económica, empleando sus ingresos en algo no muy necesario, en algo superfluo, como dice la Ley "suntuario", pues la asistencia a un espectáculo flamenco revela una capacidad económica determinada, que el legislador ha entendido que debe gravar como gasto suntuario, con objeto de no gravar otros productos o actividades no cualificadas de suntuarias, que en otro caso tendrían que quedar sujetas a imposición con objeto de atender al sostenimiento de las cargas públicas.) (Sentencia de 11 de febrero de 1987. Sala 3. ${ }^{a}$ Pujalte Clariana. Ar. 536.) 
2. Impuesto sobre radicación. Locales destinados a oficinas de la Caja de Ahorros de Pontevedra

«... Esta larga, aunque no exhaustiva enumeración de actividades permitidas a las Cajas de Ahorro, rebasan el limitado campo de actuación que a dichas Entidades permitía su Estatuto de 1933 y obligan a rechazar el argumento de la Entidad apelante de que las Cajas de Ahorro no desarrollan actividad industrial o mercantil y sus actividades están exentas de ánimo de lucro, y deben estarlo, por lo tanto, y con carácter general de Impuesto sobre radicación. Por lo tanto, no siendo suficiente el hecho de ejercer la actividad como Cajas de Ahorro para obtener la exención del Impuesto, era preciso justificar cuáles eran las actividades benéfico-sociales o deportivas a las que destinaba sus locales la Entidad apelante, justificación que ni siquiera se ha intentado en vía administrativa o judicial, y por lo tanto, cae por su base el argumento del apelante de que las posibles actividades que realizan las Cajas de Ahorro son un mero medio para conseguir ingresos con los que realizar sus fines, argumento que reiteradamente expone en su escrito de alegaciones, y que debe de ser rechazado, ratificándose la doctrina establecida por esta Sala para supuestos iguales.) (Sentencia de 11 de febrero de 1987. Sala 3. ${ }^{a}$ Martín Herrero. Ar. 538.)

\section{CONTRATOS}

1. Contrato de arrendamiento celebrado por el Jefe provincial del Servicio Nacional de Cereales (SENPA) y el Presidente de la Junta Rectora de la CFC para la instalación de oficinas. Competencia de la jurisdicción contencioso-administrativa. Actos separables. Actuación de órgano que no tenía competencia, pero que fue perfeccionado por la autorización posterior de los Servicios Centrales. Contrato sometido al Derecho público administrativo por razón de la causa y finalidad del arrendamiento concertado.

«... Y estando determinada la causa de las obligaciones de la Administración que dimanan del contrato inmediata y exclusivamente en la finalidad de atender a ese servicio público en el ámbito provincial de Cuenca, en lo que se refiere a la instalación de las oficinas de su Jefatura Provincial, a tenor del artículo 18 de la Ley de Contratos del Estado de 8 de abril de 1965: "Cuando se trate de contratos que según su naturaleza deban quedar sometidos al ordenamiento jurídico-administrativo, éste funcionará como Dere- 
cho supletorio, siendo peculiarmente aplicables con tal carácter las normas contenidas en esta Ley", se infiere la naturaleza jurídicoadministrativa de los contratos que no, teniendo por finalidad obras, gestión de servicios públicos y suministros, estén vinculados a ellos, artículo $8 .^{\circ}$ del Reglamento de 28 de diciembre de 1967, aplicables por razón de la fecha de su celebración al que es objeto de este proceso; por lo que, en consonancia con el meritado artículo $3 .^{\circ}$ de la Ley Jurisdiccional, la competencia de esta jurisdicción resulta evidente para conocer de la impugnación de los actos respecto a los cuales hubiera recaído acuerdo en relación con la perfección y ejecución del contrato que ponga fin a la vía administrativa, y en el caso de no estimarse sujeto al Derecho administrativo y sí al privado el contrato de arrendamiento, por tener como finalidad la atención de un servicio público, la cuestión relativa a su resolución debe ser dilucidada también por esta jurisdicción, en virtud del meritado precepto de la Ley jurisdiccional. Fundada la petición de declaración de nulidad de pleno derecho del contrato de arrendamiento referido en los apartados anteriores en la incompetencia del órgano de la Administración que concertó el contrato en nombre y representación del SNC con la consecuente falta de perfección del arrendamiento y en la falta del procedimiento seguido en su preparación y autorización para el concierto directo de ese arrendamiento, vicios o defectos atribuidos a unos actos de la Administración sometidos al Derecho público administrativo que sirven de soporte a la propia contratación y que por su naturaleza se hallan regulados por las normas administrativas especiales o generales de la contratación administrativa $y$, por éste, sometidos al conocimiento de esta jurisdicción, según el artículo $1 .^{\circ}$ de la Ley Judicial, criterio doctrinal y jurisprudencial, que tuvo una regulación legal y reglamentaria en la Ley de 8 de abril de 1965 y Reglamento de 28 de diciembre de 1967, sobre contratos del Estado, artículo $18.3 .^{\circ}$ y 13 , respectivamente; artículo $4 .^{\circ}, 3-A$ de la Ley reformada por la de 17 de marzo de 1973, y 14 de su Reglamento, que atribuye a la jurisdicción contencioso-administrativa la competencia para conocer de la impugnación de los actos jurídicos separables relativos a la preparación, competencia y adjudicación del contrato cuyos efectos estén sometidos al Derecho privado, resulta intrascendente la naturaleza jurídico-administrativa del arrendamiento, objeto de este proceso, en el que los actos impugnados de la Administración sujetos al Derecho administrativo, en el supuesto de ser declarados nulos, darían lugar a la nulidad del contrato, fuere cual fuere el régimen jurídico aplicable al mismo; no obstante lo cual fundada la sentencia apelada en la inadmisibilidad del recurso por entender el Tribunal a quo que el contrato se haya regulado por el 
Derecho privado, procede a afirmar su naturaleza jurídico-administrativa; y que no podía declararse inadmisible la reclamación jurisdiccional contra unos actos presuntos, por silencio administrativo de la Administración, desestimatorios de una pretensión de nulidad de un contrato basada en la de pleno derecho de unos actos separables; por lo que procede revocar la sentencia apelada.) (Sentencia de 17 de noviembre de 1986. Sala 4. ${ }^{a}$ García Estartús. Ar. 403.)

2. Contrato de Servicios. El Consejo de Administración del Organo Especial de Gestión de los Servicios Benéfico-Sanitarios Insulares del Cabildo Insular de Gran Canaria acordó adjudicar los servicios de limpieza del Hospital Insular, Escuela y Residencia de ATS, a una empresa privada. Prórroga forzosa del contrato y revisión de precios.

«La principal cuestión a resolver en los presentes actos se concreta en determinar si el supuesto de prórroga forzosa, impuesto al contratista por la Administración al amparo del artículo 59 del Reglamento de Contratación de las Corporaciones Locales de 1953, es equiparable, a los efectos de la revisión de precios interesada, al del uso por la Administración de las facultades que forman el contenido del ius variandi. La indicada cuestión preciso es resolverla en el sentido en que lo hace la sentencia apelada, esto es, en el de entender que los referidos supuestos son equiparables a los efectos de que se trata y a la argumentación que en dicha sentencia se expone, y que ha sido aceptada, hay que añadir que esta Sala, en sentencia de 22 de marzo de 1985 (R. 2.846), conoció de un caso similar al que ahora nos ocupa, y en la misma expresó que no se está ante "un caso de prórroga expresa o tácita del contrato con plena aplicación de la cláusula $9 .^{a}$ que excluye la revisión, sino ante una situación excepcional en que denunciado el contrato en la forma legalmente establecida y pactada, la Administración, por razones de interés público, unidas a la necesidad de continuidad del servicio $-y$ mientras no se seleccione al nuevo contratista- impone coactivamente la permanencia del anterior con unas consecuencias equiparables a las producidas cuando la Administración hace uso de las facultades que forman el contenido del ius variandi, con la ineludible contrapartida de la compensación económica a favor del contratista o concesionario de un servicio público", como es el caso al tratarse de un contrato de limpieza del Hospital Insular.) (Sentencia de 18 de noviembre de 1986. Sala 4. ${ }^{a}$ Garcia-Ramos Iturralde. Ar. 410.) 


\section{RESPONSABILIDAD PATRIMONIAL}

1. Nexo causal. Rotura de cable subterráneo propiedad de la Compañía Telefónica Nacional ocasionando por pala mecánica de Corporación local cuando realizaba obras

«... La responsabilidad patrimonial objetiva de la Administración no supone que la obligación de indemnizar nazca siempre que se produce una lesión por el funcionamiento normal o anormal de los servicios públicos, sino que es preciso que entre la lesión y el funcionamiento haya un nexo de causalidad objetiva del que resulte que aquella lesión es consecuencia de este funcionamiento y sin que en dicha relación de causa efecto intervenga la conducta culposa del perjudicado, pues si esta intervención es tan intensa que el daño no se hubiese producido sin ella, es obvio que no puede imponer a la Administración el resarcimiento de una lesión económica cuya causa eficiente es imputable al propio dañado, puesto que el éxito de una reclamación de estas características exige no sólo demostrar que el daño fue causado por las obras municipales, sino que las instalaciones dañadas cumplían las mínimas condiciones de seguridad y protección y discurrían por lugar de emplazamiento adecuado del cual tuviese conocimiento el Ayuntamiento, ya que en otro caso quiebra la causa de imputación de la responsabilidad de la Administración que aparece así únicamente referible a la propia Compañía perjudicada por ser su negligencia el origen eficiente de los daños y perjuicios que reclama." (Sentencia de 19 de enero de 1987. Sala 4. ${ }^{a}$ Bruguera Manté. Ar. 426.)

\section{EXPROPIACION FORZOSA}

1. Acuerdo del Jurado Provincial de Expropiación que señaló el justiprecio de una finca expropiada para la instalación de ampliaciones militares. Excepción a la prevalencia de sus valoraciones

«El Letrado del Estado combate la sentencia apelada por entender que la valoración efectuada por el Jurado, que goza de la presunción de legalidad y acierto que le atribuye la jurisprudencia, no puede quedar destruida por el parecer de unos profesionales que emitieron su informe a instancia de la parte expropiada. Este alegato tendría fuerza si no existiera otra prueba que el informe emitido por el ingeniero agrónomo aportado ya en vía administra- 
tiva -pues su carácter no contradictorio impide que pueda tomarse como prueba pericial en el proceso-, pero no es así, ya que en los actos obra otro informe de perito procesal, también ingeniero agrónomo, en el que razonadamente se valora el terreno de 250 pesetas metro cuadrado, cifra superior a la fijada por el Jurado y a la tomada en cuentas por la Audiencia Territorial, y la masa forestal a razón de 1.425 pesetas unidad, los álamos, y de 5.850 pesetas unidad, los robles, valores que acepta la sentencia impugnada por reputar adecuado en este punto el informe del empresario perito, sin que por el Letrado del Estado se haya sometido a crítica el resultado de dicha prueba ni en el escrito de conclusiones ni en las alegaciones efectuadas en el presente recurso." (Sentencia de 5 de enero de 1987. Sala 5. ${ }^{a}$ Rodríguez García. Ar. 240.)

2. Expropiación en beneficio de Corporaciones locales. Justiprecio que ha de tenerse en cuenta para calcular los intereses. Retasación

«El pago de intereses es una obligación accesoria de la principal de abono del justiprecio de los bienes expropiados impuesta por ministerio de la Ley, concretamente en los artículos $52.8,56$ y 57 de la LEF, que determina amplias facultades en el Tribunal que resuelve, también justificadas por razones de economía procesal y con el fin de evitar nuevas actuaciones en procedimiento distinto o en orden a su pago y precisar todas las circunstancias que permitan su cuantificación, según ya declaró la Sala en sentencia, entre otras, de 6 de octubre de 1986. Los artículos 36, 43 y 45 de la Ley General Presupuestaria de 4 de enero de 1977, sobre abono de intereses, no son de aplicación cuando la expropiación se lleva a efecto por o en beneficio de una Corporación local o de un particular-sentencias de 12 de junio, 28 del mismo mes y 28 de noviembre de 1985 (R. 4.169, 3.534 y 5.538); 28 de febrero, 6 de marzo, 18 de abril y 28 de noviembre de 1986 (R. 441, 1.030, 2.612 y 6.639)-, devengándose el legal del 4 por 100 establecido en el artículo 1.108 del Código civil hasta el 3 de julio de 1984, en que entró en vigor la Ley 24/1984, de 29 de junio, desde la que, por tener los intereses la consideración de frutos civiles, de conformidad en el párrafo tercero del artículo 355 del Código civil, entendiéndose producidos por días según el párrafo último del artículo 451 del mismo texto legal -sentencias de 21 de abril y 10 de junio de 1986 (R. 2.013 y 3.234)-, deberán abonarse los establecidos para cada período de tiempo por las Leyes Presupuestarias, hasta el 12 de julio de 1985, fecha de la sentencia de primera instancia, desde la que deberán asociarse los establecidos 
en los párrafos cuarto y quinto del artículo 921 de la Ley de Enjuiciamiento Civil, de acuerdo con la facultad conferida en el referido precepto para los supuestos de revocación parcial de la sentencia apelada, habida cuenta que el importe del justiprecio no es objeto de impugnación en el recurso. Cuando en el procedimiento de retasación se establece una nueva valoración del bien o derecho expropiado, de acuerdo con la doctrina establecida por la Sala en sentencias de 14 de febrero, 23 de mayo y 7 de diciembre de 1977 (R. 670, 2.254 y 4.682), 20 de diciembre de 1978 (R. 4.194), 11 de diciembre de 1979 (R. 4.284); el justiprecio primitivo es el que ha de tenerse en cuenta para calcular los intereses de los artículos $52.8 .^{\circ}, 56$ y 57 desde los seis meses de haberse iniciado el expediente expropiatorio por demora en su tramitación o desde el día siguiente a la ocupación en los casos de expropiación vigente cuanto la ocupación hubiere tenido lugar antes del transcurso de dicho plazo, hasta el día anterior a la solicitud de retasación, calculándose sobre el nuevo justiprecio los devengados desde la fecha de presentación de la solicitud de retasación hasta la de pago del mismo, sin que pueda simultanearse la percepción de distintas clases de intereses y con deducción de los correspondientes a cantidades que hubiesen sido objeto de pago o depósito precio y desde la fecha en que lo fueron." (Sentencia de 21 de enero de 1987. Sala 5. ${ }^{\circ}$ González Mallo. Ar. 261.)

\section{DOMINIO PUBLICO}

1. Vía pecuaria. Uso de terrenos contrario à la afectación basado en títulos inscritos. Falta de deslinde y amojonamiento. Resolución ministerial que impone sanción de multa y demolición por invadir parte de los terrenos de vía pecuaria al haber anexionado a su finca, mediante la construcción de naves, parte de suelo de dominio público

«Por ello, y aunque en la orden de clasificación aparezca descrita la vía, fijada su dirección y demás características no deja de ser cierto también - tal como resalta la sentencia apelada y la propia Administración al resolver un recurso análogo y referido a la misma vía pecuaria el 15 de febrero de 1985 , etc.- que en el supuesto contemplado falta el deslinde y amojonamiento de la vía pecuaria, la ausencia de signos exernos reveladores del uso vial pecuario -o límites reales por donde discurre- y por el contrario existen actos de uso de los terrenos contrarios a la afectación basados en títulos inscritos, etc., lo cual patentiza la dificultad en que nos encontra- 
mos y con el alcance que se deducen del expediente de sanción, en el que falta la delimitación de la vía o su perímetro en la realidad, por lo que el deslinde previo (art. 24.3 del Real Decreto 2876/1978) parece manifestarse como operación jurídica-técnica indispensable para poder apreciar, en consecuencia, el alcance de la ocupación o invasión denunciada.» (Sentencia de 19 de enero de 1987. Sala 4. ${ }^{a}$ Martín Martín. Ar. 430.)

2. Construcción de puerto deportivo. La competencia para otorgar la concesión de construcciones dentro del mar es del Estado. El Ayuntamiento tiene competencia para vigilar las posteriores utilizaciones del suelo

«... La constante jurisprudencia citada en el recurso ha declarado en síntesis que el dominio público marítimo forma parte del término municipal y que las competencias del Estado no son para fines urbanísticos, ámbito en que las tienen los Ayuntamientos, cuya jurisdicción se extiende a la zona marítimo-terrestre $y$ a las superficies que la continúen dentro del mar territorial al dejar la Ley de Costas de 26 de abril de 1969 a salvo las competencias municipales según la Ley de Régimen Local, lo que conlleva que al otorgarse una concesión estatal, no se dispensa de la necesidad en su caso de obtener la licencia municipal, urbanística. La sentencia recurrida no contradice esta doctrina, sino que partiendo de ella y de la unidad del término municipal, sin enclaves exentos, distingue en las concesiones sobre mar territorial dos clases: La inicial, para la cual se reconoce competencia exclusiva al Estado, y la posterior, cuando los terrenos ganados al mar a consecuencia de las obras del puerto por accesión artificial, pasan a formar parte de la zona marítimo terrestre, momento en que hay que observar la ordenación urbanística para los usos del suelo, siendo entonces exigible la licencia municipal correspondiente.) (Sentencia de 4 de febrero de 1987. Sala 3. ${ }^{a}$ Carretero Pérez. Ar. 501.)

\section{SERVICIO PUBLICO}

1. La actividad de Radiodifusión y Televisión como servicio público cuya titularidad corresponde al Estado. La atribución de frecuencias se efectuará por el Gobierno. Denegación de inscripción en el Registro de Frecuencias de Transmisores de UHF

"La Sala de Primera Instancia planteó cuestiones de constitucionalidad del artículo $1 . \circ, 2$ de la Ley de 4/1980, de 10 de enero, 
reguladora del Estatuto de la Radio y la Televisión, en cuanto debatiéndose en el proceso el ejercicio del derecho de libre expresión y difusión reconocido por el artículo 20 de la Constitución, es necesaria, a tenor del artículo 81.1 de esta norma fundamental, Ley Orgánica para el desarrollo de los Derechos Fundamentales y de las Libertades Públicas. El Tribunal Constitucional, por sentencia de 24 de julio de 1986, resolviendo la cuestión planteada, declaró: "La falta de relevancia del precepto cuestionado respecto del fallo a dictar por la Audiencia Nacional, carencia de relevancia que en este momento debe llevar a la desestimación de la cuestión por no haber lugar a pronunciarse acerca de la constitucionalidad de la norma cuestionada." Y esta sentencia expresó como fundamento de su decisión, ahora expuesto en sintesis, "que la eventual declaración de inconstitucionalidad del artículo $1 . \circ 2$ de la Ley $4 / 1980$ no permitiría atender la pretensión deducida en vía contenciosa, toda vez que la inscripción en un registro de concesiones de servicio público sólo tiene sentido en la medida en que dicho servicio siga mereciendo el carácter de tal. Por otro lado, no puede olvidarse que la declaración que lleva a cabo el precepto cuestionado de la actividad de Radiodifusión y Televisión como servicio público, no supone, por sí sola, un obstáculo insalvable para la gestión por los particulares de esa actividad; ni la ausencia de tal declaración representaría más la existencia de un derecho preestablecido a inscribir y reservar, en el correpondiente Registro, frecuencias determinadas de Radio y Televisión a favor del particular que lo solicitase. Consecuentemente, no tiene, a estos efectos, carácter de inconstitucional el artículo $1^{\circ}, 2$ de la Ley 4/1980, que califica a la Radiodifusión y a la Televisión como servicios públicos cuya titularidad corresponde al Estado.» (Sentencia de 16 de enero de 1987. Sala 3. ${ }^{a}$ Ar. 9.)

\section{El suministro de energía eléctrica como un servicio público. Naturaleza mixta}

"Configurado el suministro de energía eléctrica como un servicio público cuya reglamentación corresponde al Ministerio de Industria, según reza el artículo $1 .^{\circ}$ del Reglamento de Verificaciones, aprobado por Decreto de 12 de marzo de 1954, con una intervención acusada del Estado en garantía de la seguridad e interés de consumidores y empresas a cargo de las Delegaciones de Industria a las que corresponde, entre otras, la vigilancia de las características de la energía, funcionamiento de los aparatos medidores, equidad de facturaciones $y$ condiciones de seguridad que se enumeran en su artículo $2 .^{\circ}$, la sentencia apelada parte ajustada- 
mente para enmarcar las cuestiones planteadas por la denuncia del contrato de suministro en cuanto afecta al hecho del mismo, de resaltar su naturaleza mixta en la relación Empresa-usuarios, con una vertiente reglamentaria o estatutaria en que las relaciones quedan afectadas al ámbito del Derecho Público, con intervención de la Administración, que a través de sus organismos del Ministerio de Industria juega un trascendente papel en la organización, vigilancia y control del servicio público, y otra, la privada, en que las relaciones entre las partes suministradora y abonado que la disfruta a cambio de precio pactado, no derivan de mandato administrativo en cuanto decididas por la voluntad de las partes contratantes, aun cuando estén bajo la vigilancia y control de los poderes públicos a través del cumplimiento de las normas reglamentarias en evitación de las consecuencias que para el interés público pueda tener el incumplimiento del contrato no dando la energía la suministradora o no satisfaciendo puntualmente su obligación de pago la abonada, con las consecuencias que en cuanto al suministro pueda ello acarrear.) (Sentencia de 13 de febrero de 1987. Sala 3. ${ }^{a}$ Español La Plana. Ar. 547.)

\section{RECURSOS ADMINISTRATIVOS}

1. Resoluciones tardías. Eficacia de las resoluciones tardías del Registro de la Propiedad Industrial. El artículo 94 de la Ley de Procedimiento Administrativo concede un derecho de opción a quienes recurren en reposición. Supuestos en los que del acto originario hayan nacido derechos subjetivos

«En relación con el primer motivo de impugnación de la resolución recurrida, que la apelante trata de fundamentar en su carácter extemporáneo y que a su juicio han de concurrir a su ineficacia, ha de ponerse de relieve que si bien es cierto que las declaraciones contenidas en sentencias de este Tribunal sobre la eficacia de las resoluciones del Registro de la Propiedad Industrial dictadas con posterioridad al transcurso de un año desde la interposición del recurso de reposición han sido en ocasiones contradictorias durante las pasadas décadas ha de tenerse en cuenta que ya en la presente se ha consagrado una línea constante que da plena validez a tales resoluciones en base a que el artículo 94 de la Ley de Procedimiento Administrativo concede a quienes recurren en reposición un derecho de opción entre acogerse a la ficción del silencio administrativo e interponer contra la desestimación presunta el pertinente recurso jurisdiccional o bien esperar a la resolución 
expresa que debe dictarse por la Administración, según dispone el número 3 del artículo 94 de la Ley referida, que no establece límite temporal alguno para el cumplimiento de tal deber, por lo que obliga al recurrente a interponer recurso de reposición equivale a privarle del derecho de opción que le ha sido concedido, ni más ni menos, que por una Ley; habiéndose declarado igualmente por esta Sala que la plena validez eficacia de las resoluciones tardias tienen como excepción aquellos supuestos en los que del acto originario hayan nacido derechos subjetivos en favor de alguna persona, en cuyo caso el respeto al principio de seguridad jurídica, elevado hoy al rango de principio constitucional, impone eficacia a las resoluciones tardías.) (Sentencia de 14 de enero de 1987. Sala 3. ${ }^{a}$ Madrigal García. Ar. 1.)

\section{JURISDICCION CONTENCIOSO-ADMINISTRATIVA}

1. Actos impugnables. Instrucción del Almirante Jefe del Estado Mayor de la Armada sobre organización en la sucesión de mandos, jefaturas y cargos directivos referentes a la Fuerza Naval. Actos políticos del Gobierno

«El Auto impugnado, de la Sala Cuarta de la Audiencia Territorial de Madrid, declara la inadmisbilidad del recurso contenciosoadministrativo interpuesto contra la Instrucción número 6/1982, del Almirante Jefe del Estado Mayor de la Armada, de 8 de noviembre, sobre organización en la sucesión de mandos, jefaturas y cargos directivos en general referentes a la Fuerza Naval, por entender que está incluido en el artículo $2 .^{\circ}$ de la Ley reguladora de esta Jurisdicción, por no ser materia administrativa, y, por tanto, fuera de su control los actos políticos que afectan al mando $y$ organizativa militar (como afirma el Auto recurrido), sino los actos políticos del Gobierno, como son los relativos al mando y organizarefiere a todos los actos dictados en el ejercicio de la potestad organizativa militar (como afirma el auto recurrido), sino los actos políticos del Gobierno, como son los relativos al mando y organización militar, por lo que se ha venido interpretando por la jurisprudencia han de ser actos dictados por el Gobierno en pleno, por el Consejo de Ministros, y no por otro órgano del mismo: En este caso no se ha dictado por el Consejo de Ministros, sino por el Almirante Jefe de Estado Mayor de la Armada, en virtud de atribuciones delegadas por Real Decreto, lo que impide la aplicación de ese precepto limitativo de la competencia de la jurisdicción ordinaria contencioso-administrativa; y con posterioridad a la 
vigencia de la Constitución, tanto su artículo 24-1, que concede la tutela efectiva por los Jueces y Tribunales, como el 106, control de la potestad reglamentaria, legalidad de la actuación administrativa, así como el sometimiento de ésta a los fines que la justifican y el artículo $8 .^{\circ}$ de la Ley Orgánica del Poder Judicial han incluido decididamente estas regulaciones en el ámbito de la revisión jurisdiccional, en cuanto su adecuación al ordenamiento jurídico, por lo que es admisible el recurso para examinar esa adecuación a Derecho, como ya se dijo en sentencia de esta Sala de 22 de septiembre de 1986 (R. 4.801).» (Sentencia de 19 de enero de 1987. Sala 5. ${ }^{a}$ Falcón García. Ar. 235.)

2. Legitimación corporativa. Examen de este concepto después de la tutela efectiva de los Jueces y Tribunales proclamada en la Constitución. Consejo Superior de Colegios de Titulares Mercantiles

«Es preciso ante todo estudiar la causa de inadmisibilidad de este recurso contencioso-administrativo aducida por el Letrado del Estado y por parte coadyuvante, Instituto de Censores Jurados de Cuentas, que sitúan en la carencia de legitimación activa de los recurrentes, y que tiene su soporte en los artículos 28 y $82, b)$ de la Ley de esta Jurisdicción y con el fin de resolver este punto puede decirse inicialmente que conviene recordar la tendencia actual sobre esta materia de las inadmisibilidades en este tipo de procesos, iniciada incluso antes de la vigencia de la Constitución de 1978, y acentuada tras ella, en el sentido de que no deben utilizarse criterios rigoristas y de índole meramente formal, procurando más bien salvar todo aquello que no constituya en verdad un auténtico obstáculo para el examen y decisión de las cuestiones de fondo que el proceso ofrezca. No se puede aceptar que carezca de legitimación el Consejo Superior de Titulares Mercantiles debido a que a su vez esté desprovisto del interés a que se alude en el artículo 28 antes citado, para atacar el Real Decreto objeto de este recurso, en su integridad, y subsidiariamente en fragmentos del mismo, porque está claro que si de lo que se trata en dicha disposición es de la aprobación de los Estatutos rectores de una actividad profesional, que se desvincula de aquel Consejo, y que viene a regular campos afines $y$ a veces coincidentes, aquella alegación de carencia de interés no pasa de ser invocación desacertada de un medio defensivo... porque la restricción a determinadas corporaciones, colegios o entes, de la legitimación para impugnar disposiciones de 
carácter general, ha quebrado tras la vigencia de nuestro primer texto, en particular por lo que dispone el artículo 24 del mismo sobre tutela judicial efectiva. Todo ello aparte de que la solución contraria a nada positivo o práctico conduciría, ante la presencia cuya legitimación no puede ponerse en duda, lo que obligaría igualmente al examen y decisión de lo que es el fondo de este recurso.» (Sentencia de 27 de enero de 1987. Sala 3. ${ }^{a}$ Roldán Martínez. Ar. 220.)

\section{Legitimación por subrogación de compañía aseguradora en el lugar de los perjudicados a quienes han indemnizado}

"A la pretensión expuesta opone en primer término el defensor de la Administración demandada, la causa de inadmisibilidad del recurso prevista en el artículo 82 , b) de la Ley Reguladora de la Jurisdicción (R. 1.956, 1.890 y N. Dicc. 18.435), al negar legitimación activa a la entidad demandante para entablar la acción promovida, tema que por su naturaleza ha de tratarse con carácter previo a la cuestión de fondo y al efecto se ha de señalar que, además de ser criterio actual de la jurisprudencia sobre el particular, una interpretación amplia del concepto de legitimación como cauce de acceso de cualquier persona física titular de un interés a la vía jurisdiccional en demanda de protección, potenciando la posibilidad de la tutela judicial efectiva proclamada por la Constitución -sentencias de 18 de febrero y 11 de junio de 1982 (R. 553 y 4.585), 10 de febrero de 1983 (R. 752 ), 24 de febrero de 1984 (R. 984) y 25 de mayo de 1985 (R. 2.625)- la legitimación por subrogación de las compañías aseguradoras en el lugar de los perjudicados a quienes han indemnizado ha sido expresamente reconocida por la Jurisprudencia de modo concreto en las sentencias de 6 de marzo y 11 de noviembre de 1985 (R. 2.807 y 5.547) para entablar acciones de esta naturaleza, como titulares de un interés directo nacido de la subrogación operada al amparo de lo dispuesto en el artículo 43 de la Ley 50/1980, de 8 de octubre, del Contrato de Seguro, en cuya virtud el asegurador, una vez pagada la indemnización, podrá ejercitar los derechos y acciones que por razón del siniestro correspondan al asegurado frente a las personas responsables del mismo, hasta el límite de la indemnización.) (Sentencia de 11 de febrero de 1987. Sala 3. ${ }^{a}$ Garralda Valcárcel. Ar. 535.) 
4. Apelación contra recurso seguido al amparo de la Ley 62/1978. Efectos de la falta de «escrito razonado». Doctrina jurisprudencial

«En más de una sentencia y también en el reciente Auto de 13 de octubre de 1986 hemos explicado cómo el artículo 9. ${ }^{\circ}$, párrafo $2 .^{\circ}$, de la Ley $62 / 1978$, de 26 de diciembre, establecerá con talante claramente imperativo que "la apelación se preparará mediante escrito razonado ante la Sala sentenciadora". Se refunden así, en un solo trámite, las fases de interposición del recurso y formalización del recurso. Ahora bien, los efectos jurídicos del incumplimiento de este mandato no aparecen previstos y la jurisprudencia tampoco ha marcado una pauta inequívoca. En efecto, esta Sala ha dicho a veces que la omisión de aquel "escrito razonado" impide entrar a conocer de las cuestiones controvertidas, criterio que con esa eficacia obstativa inicial configura un presupuesto de admisibilidad de la impugnación -sentencia de 3 de octubre de 1984 (R. 5.568)-. En otras ocasiones, las consecuencias desfavorables del incumplimiento han sido moduladas con alguna flexibilidad, en cierto aspecto incoherente con el punto de partida, ya que la inadmisbilidad procedente en principio, se proclama con la salvedad de que no se aprecie un claro y evidente error en la resolución apelada, lo cual implica a su vez el enjuiciamiento de la cuestión de fondo -20 de octubre de 1984 (R. 4.987), 25 de mayo y 20 de junio de 1985 (R. 2.624 y 3.848).

En definitiva, ha de prevalecer la primera de estas dos tendencias jurisprudenciales, a causa del carácter no sólo preferencial (urgente), sino también sumario (o sea, de cognición limitada) propio de este proceso especial para la protección de los derechos fundamentales de la persona. En efecto, conviene recapacitar que, por una parte, los plazos procesales (y, entre ellos, el de preparación del recurso) son de caducidad. Por otra, como indica nuestra sentencia de 19 de enero de 1985 (R. 453), la personación ante la Sala correspondiente del Tribunal Supremo es la única oportunidad ofrecida a los apelados para poder contradecir las alegaciones de los apelantes, quedando aquéllos en ostensible situación de indefensión si los argumentos utilizadọs frente a la resolución impugnada se producen $y$, por tanto, se conocen cuando ya no queda ocasión para intentar desvirtuarlas, combatirlas en suma. Inciden así de consumo los principios de preclusividad y de contradicción, propios de este sector del Derecho. El Tribunal Constitucional, en su sentencia de 8 de octubre de 1985, parece aceptar tal planteamiento en su conjunto, aun cuando sólo afronte un aspecto 
parcial. Según esta decisión, el apelado no se encuentra aquí en situación de indefensión, precisamente porque en el momento de comparecer ante nosotros tiene a la vista los alegatos del escrito razonado mediante el cual debe prepararse el recurso." (Sentencia de 20 de enero de 1987. Sala 3. ${ }^{a}$ Mendizábal Allende. Ar. 18.)

\section{FUNCIONARIOS PUBLICOS}

1. Incompatibilidades. Practicante de la zona del INSALUD y profesor de EGB. No puede invocarse los derechos adquiridos como una petrificación del ordenamiento jurídico que suponga impedir el ejercicio por parte de la Administración de la potestad organizativa y reglamentaria

«La Ley 53/1984, de 26 de diciembre, sobre incompatibilidades, tiene como ratio legis, presidiendo toda su normativa, la dedicación del personal al servicio de la Función Pública a un solo puesto de trabajo, estableciendo, como regla general, que al personal en ella comprendido no pueden contabilizársele dos puestos de trabajo en el sector público (art. 1.1), sin posibilidad de percepción de más de una remuneración con cargo a los presupuestos de las Administraciones Públicas, Organismos y Empresas de ellas dependientes (art. 1.2) e impidiendo, o incompatibilizando, el ejercicio de la función pública con cualquier cargo, profesión o actividad, pública o privada, que impida o menoscabe el estricto cumplimiento de los deberes o comprometer la imparcialidad o independencia del funcionario (art. 1.3), existiendo unos supuestos en los que se permite tal compatibilidad-que por vía de excepción se contemplan en la Ley (arts. $3 .^{\circ}, 4 .^{\circ}$ y $5 . .^{\circ}$ - y sin que las actividades desempeñadas por el apelante se encuentren incluidas en las excepcionales legales admitidas, sino por el contrario incursas en la incompatibilidad general que se establece en el artículo 1 de la Ley, ya que como funcionario desempeñaba el puesto de practicante de APD y profesor de EGB percibiendo sus remuneraciones, en ambos casos, con cargo a los Presupuestos Generales y siéndole, por consiguiente de aplicación la regla general, con independencia de si el desempeño de ambas funciones incide, impidiendo o menoscabando, el estricto cumplimiento de sus deberes como funcionario en ambos casos, por ser este tema una cuestión a dilucidar o considerar, únicamente, en los supuestos de excepcionalidad legal para la autorización o denegación de un segundo puesto de trabajo, lo que aconseja la desestimación de la 
pretensión del recurrente apelante y la confirmación de la sentencia apelada.

La decisión que ratificamos no incide en la esfera de los derechos adquiridos por aplicación del principio de irretroactividad de las disposiciones restrictivas de derechos individuales que consagra el artículo 9.3 de nuestra Constitución, pues como ha declarado el Tribunal Constitucional -sentencias 27/1981, de 20 de julio, y 6/1983, de 4 de febrero-, los derechos adquiridos, en conexión con el principio de irretroactividad de las normas restrictivas de derechos individuales, no pueden invocarse como una defensa de una petrificación del Ordenamiento jurídico que suponga impedir el ejercicio por parte de la Administración de la potestad organizativa y reglamentaria de la que dispone, impidiéndole establecer nuevos sistemas de organización y retribución, aunque respetando, de forma global, los derechos subjetivos adquiridos, aclarándose por la sentencia de 10 de abril de 1986 que "lo que se prohíbe en el artículo 9.3 es la retroactividad, entendiéndose como incidencia de la nueva Ley (o norma) en los efectos jurídicos ya producidos de situaciones anteriores, de suerte que la incidencia en los derechos, en cuanto a su proyección hacia el futuro, no pertenece al campo estricto de la irretroactividad", y sin que la materia relativa a la privación de un segundo puesto de trabajo sin la correlativa compensación económica, sea tema a dilucidar en el presente proceso en el que el recurrente nada postula al respecto ni ha existido acto previo administrativo pronunciándose sobre ello.» (Sentencia de 19 de enero de 1987. Sala 5. Hernando Santiago. Ar. 245.)

2. Excedencia de funcionarios. Comunidad Autónoma de Andalucía. Integración de ATS en Equipos de Atención Primaria Médica, con alternativa de excedencia. Principio de igualdad

«Se alega, igualmente, por los apelantes que las resoluciones impugnadas contienen tres discriminaciones para los mismos que suponen violaciones del artículo 14 de la Constitución, consistentes en que a los que no opten por la integración se les declara en situación de excedencia y tal situación o no afecta a los funcionarios del Estado o de otras Comunidades Autónomas que optan por continuar en su plaza, discriminación, que dicen, está en contradicción con el régimen uniforme e igualitario que para todos los funcionarios públicos viene consagrado en el artículo 1.3 de la Ley 30/1984, de Medidas para la Reforma de la Función Pública, que cita expresamente como básico el artículo 29 de la misma, que regula la excedencia en forma igualitaria para todos ellos, care- 
ciendo de fundamento legal y racional toda diferencia en cuanto al régimen de excedencia que imponen los acuerdos recurridos dictados en ejecución de la Orden de Consejería de Salud y Consumo de la Junta de Andalucía de 7 de noviembre de 1984, cuando del Derecho del Estado contenido en el Real Decreto básico $137 / 1984$ no establece la excedencia para los funcionarios sanitarios que opten por continuar en el desempeño de la plaza que en propiedad vienen desempeñando. Mas tal argumentación no puede ser compartida por esta Sala, pues es obvio que a efectos de una posible desigualdad no puede plantearse la comparación en términos en que lo hacen los apelantes, a saber entre los funcionarios de su Comunidad Autónoma que por no integrarse, dicen, quedan en situación de excedencia y los funcionarios de otras Comunidades Autónomas que no quedan afectados por la excedencia si continúan en su plaza, pues son dos situaciones totalmente distintas, amén de que los apelantes parten de un error esencial en su planteamiento, a saber, que a los que no opten por la integración se les declara en situación de excedencia, pues si bien es cierto que en la comunicación de 10 de abril de 1986 se les dice que caso de rechazar la integración pasarán a la situación de excedencia en la forma contemplada en la legislación vigente, de conformidad con el artículo $4 .^{\circ}$ de la Orden de 7 de noviembre de 1984, no es menos cierto que tal Orden, que sólo contiene tres artículos, no hace referencia alguna a la situación de excedencia, como tampoco lo hace la Resolución del Delegado provincial de 11 de abril de 1986. publicada en el Boletín Oficial de la provincia de 19 de abril de 1986, aunque ello no implica que no puedan ser declarados en situación de excedencia forzosa a tenor del artículo 44 del texto articulado de la Ley de Funcionarios Civiles del Estado, aprobado por Decreto de 7 de febrero de 1964, vigente después de la publicación de la Ley de 2 de agosto de 1984, de Medidas para la Reforma de la Función Pública, hasta la publicación del Reglamento de Situaciones Administrativas de los Funcionarios Públicos de 11 de abril de 1986 (R. 1.186), cuyo artículo 14 regula la situación de excedencia forzosa. Normas que si no hubieran sido respetadas por la legislación de otras Comunidades Autónomas, distintas de las de Andalucía, impedirían, en todo caso, hablar de discriminación en relación a los funcionarios de esta última Comunidad Autónoma, pues situaciones distintas que violen tales normas no podrían nunca servir de base para fundamentar la violación del principio de igualdad.» (Sentencia de 28 de enero de 1987. Sala 3. ${ }^{a}$ Madrigal García. Ar. 224.) 
3. Retribuciones. Complemento de destino. Personal de Organismos Autónomos. Es la índole del puesto desempeñado y no las cualidades profesionales genéricas del funcionario lo que determina la procedencia de su percepción

«Reconocida la contradicción, nos hallamos en el caso de resolver cuál de las tesis opuestas es la correcta respecto al reconocimiento del derecho a percibir complemento de destino en aquellos puestos de trabajo ocupados por miembros de un cuerpo o carrera a los que se reconoce el mismo nivel de titulación y preparación, cuestión ésta tratada de modo expreso en la reciente sentencia de esta Sala de 17 de marzo de 1986 (R. 1.038)-dictada en recurso de apelación extraordinario en interés de Ley número 55.758- que afronta la misma cuestión tratada y resuelta de modo diferente en las resoluciones que aquí se comparan. En ella se estableció como doctrina legal correcta "que el complemento de destino corresponde a los funcionarios que desempeñan puestos de trabajo que requieran particular preparación o especial responsabilidad, sin que pueda ser reconocido por la mera posesión del título exigido para ingresar en un determinado Cuerpo".

A la luz de dicha doctrina, fijada por la Sala, ha de resolverse el presente recurso, y según la misma, es la índole del puesto desempeñado $y$ no las cualidades profesionales genéricas del funcionario ni el campo común en que se desarrollen sus funciones lo que determina la procedencia de la percepción del complemento de destino. Además, según se desprende del artículo $2 .^{\circ} 2$, del Decreto 889/1972, de 13 de abril, y del artículo 69 del Estatuto del Personal de Organismos Autónomos, los puestos que merezcan tal complemento serán señalados por el Gobierno a propuesta del Ministerio de Hacienda y a iniciativa de los Ministerios interesados, lo que significa que en principio no se prevé una organización totalmente horizontal de complementos de destino asignados a todos los puestos que existan en un servicio para el que se requiera solamente la preparación que se acredita con igual titulación académica, sino que forzosamente habrán de ser seleccionados dentro del ámbito en que se mueven los funcionarios del mismo cuerpo o carrera aquellos puestos en que ya por llevar aparejadas funciones directivas o ya por la carga de dificultades añadidas, sea aconsejable dotarlos de mayores estímulos económicos. El lema de igual para todos, puesto que todos pueden presumirse que saben lo mismo y que son capaces de realizar las mismas tareas, exigirá suprimir la razón esencial de los complementos de destino, es decir, declarar ilegal la noción misma de complemento de destino 
como rasgo diferenciador de los puestos de trabajo.) (Sentencia de 15 de enero de 1987. Sala 5. B Burón Barba. Ar. 245.)

4. Retribuciones. Catedráticos y profesores de Institutos de Bachillerato; profesores en prácticas e interinos

«a) El Real Decreto 493/1978 (R. 618), dictado en aplicación de la disposición final 3. ${ }^{a}$, 3, del Real Decreto 22/1977, establecido en un régimen retributivo exclusivo para los profesores que, habiendo superado las correspondientes pruebas electivas, desarrollen función docente con plena validez académica en calidad de funcionarios en prácticas y profesores interinos, en cuanto sus retribuciones básicas sean las del Cuerpo al que aspiren a ingresar o del que ocupen vacante, con lo que el precitado Real Decreto 22/1977 se apartó de lo que disponía el artículo 7 del Real Decreto 22/1977 para los funcionarios en prácticas, a los que asignaban el 75 por 100 de las retribuciones básicas del Cuerpo a que aspiren a ingresar, y siguió la pauta marcada por el Decreto 1315/1972, de 10 de mayo. b) La disposición final del Real Decreto 493/1978, que en su segundo apartado excluía para el ejercicio económico de 1978 el sistema retributivo que establecía, sustituyéndolo por un incremento del 21,5 por 100 sobre las retribuciones anuales percibidas por los profesores interinos $y$ en prácticas durante el año 1977, por igual dedicación y puesto de trabajo, sin que en ningún caso puedan superar las correspondientes a funcionarios en cuanto a las retribuciones de los profesores interinos para el ejercicio económico del año 1979, por la Ley 1/1979 (art. 9. ${ }^{\circ}$ ), y para el año 1980, por la Ley 42/1979, de 29 de diciembre (arts. $8 .^{\circ}$ y 10). c) Esta afectación no se produjo en cuanto a los funcionarios en prácticas, a los que no hacen alusión las precipitadas leyes presupuestarias y a las que es de aplicación la anterior normativa, como esta Sala ha declarado en las sentencias de 22 de abril, 3 y 13 de octubre de 1986 (R. 2.018). d) No debe olvidarse tampoco, de acuerdo con lo dicho en esta última sentencia, que la "homologación a que se refiere la disposición final del Real Decreto 493/1978 contempla una situación singular, esto es, no la de un mero funcionario que, tras superar las pruebas selectivas correspondientes para el ingreso en el Cuerpo, se encuentra en prácticas para completar su formación, sino la de un funcionario que desarrolla su función docente con plena validez académica y al que parece lógico que el ordenamiento jurídico le reconozca el derecho a percibir la totalidad de las retribuciones básicas del Cuerpo al que aspire a ingresar". Supuesto distinto al 
de profesor interino.» (Sentencia de 19 de enero de 1987. Sala 5. Fuentes Lojo. Ar. 249.)

5. Diferencias retributivas correspondientes al concepto de grado de carrera nacidas de distintas resoluciones: Judicial y administrativa. El principio de igualdad ante la Ley sólo juega dentro de la legalidad

"Con estas declaraciones del Acuerdo del Consejo de Ministros de 14 de diciembre de 1983, a los que se atuvo la Administración para el pago de recurrentes, se produjo un elemento diferenciador entre la situación jurídica individualizada de la sentencia de la Audiencia afectante al expresado Inspector y lo declarado en el Acuerdo del Consejo, que no hacía referencia a ella, aun cuando su proclamación se hiciera a consecuencia del resultado obtenido por el primer peticionario ante la jurisdicción, como se infiere del conjunto de las actuaciones y concretamente del informe del Director general de la Policía, obrante al folio $1 .^{\circ}$ del expediente $y$ de la fotocopia de la reseña de las resoluciones adoptadas por el Consejo de Ministros, en 14 de diciembre de 1983, en que se hace referencia al Acuerdo por el que se hace extensiva a todos los funcionarios del Cuerpo Superior de lo Contencioso-Administrativo de la Audiencia Territorial de Madrid y la de oficio-carta dirigido por la Secretaría Técnica a la Dirección porque no es la reseña o denominación, lo que obliga en un Acuerdo, sino su texto y parte dispositiva su contenido en fin, y.lo que el Ministerio aprobó es el Acuerdo obrante por copia en el expediente a que anteriormente se hizo referencia; por lo que creadas dos situaciones retributivas nacidas de distintas resoluciones, una para el funcionario que obtuvo la sentencia y otra para los demás a través del Acuerdo del Consejo, la discrepancia entre ambas no puede solucionarse con la invocación del principio constitucional de igualdad, puesto que no jugando éste sino dentro de la legalidad, según acaba de reiterar el Tribunal Constitucional en el fundamento $8 .^{\circ}$ de su sentencia número $151 / 1986$, de 1 de diciembre, previamente habría de determinarse cuál era la cuantía de la gratificación grado de carrera, para los actores, mediante la impugnación del Acuerdo del Consejo de Ministros si estimaban no era la declarada la que les correspondía, al establecerse junto al derecho a la retribución la necesidad de reintegrar la percibida en sustitución como retribución básica provisional, cuestión de legalidad constitucional conforme por citar alguna además de las invocadas en la sentencia apelada, la número 23 de 1984, de 20 de febrero, del Tribunal Constitucional, en cuyo fundamento $2 .^{\circ}$, párrafo $3 .^{\circ}$, se limita este proceso al contenido 
constitucional, que es lo que permite el que con independencia de él, pueda acudirse al ordinario para fiscalizar las cuestiones de legalidad.) (Sentencia de 29 de enero de 1987. Sala 3. ${ }^{\circ}$ Español La Plana. Ar. 225.)

6. Acceso al Cuerpo de Profesores Titulares de Universidad mediante pruebas de idoneidad. No cabe sustituir por el criterio jurisdiccional el de la Comisión nombrada al efecto. Discrecionalidad técnica. Vinculación para la Administración de las resoluciones de los Tribunales de concursos. Conservación de las actuaciones correspondientes a quienes superaron las pruebas de idoneidad

"La Administración se encuentra en principio vinculada por las resoluciones de los Tribunales $u$ órganos calificadores designados para juzgar las pruebas selectivas para el ingreso en la Administración Pública y prueba de que las calificaciones efectuadas por aquéllos no pueden ser sustituidas por una decisión de la Administración es que cuando ésta revisa, conforme a los artículos 109 y siguientes de la Ley de Procedimiento Administrativo (o en vía de recurso), las resoluciones de dichos órganos deben practicarse de nuevo las pruebas o trámites afectados por la irregularidad. Así se dispone expresamente en el artículo 10 del Reglamento de Oposiciones y Concursos, aprobado por Real Decreto 1411/1986, de 17 de junio (R. 1.156 y N. Dicc. 14.627), y se reitera en el artículo 20.2 del nuevo Reglamento General para el ingreso del personal al servicio de la-Administración del Estado, aprobado por Real Decreto 2223/1984, de 19 de diciembre (R. 2.873).

De lo expuesto se infiere que no pueden prosperar las pretensiones de los actores -apelantes en esta alzada jurisdiccionalenderezadas a obtener en sede judicial una declaración de idoneidad o alternativamente un pronunciamiento de equiparación a los candidatos que obtuvieron tres puntuaciones de seis o superior, ya que ello entrañaría efectuar un control técnico de la actuación de la Comisión, y no de legalidad, que es el único que podemos realizar -art. 106. 1 de la Constitución-. Este Tribunal, en sentencias de 9 y 19 de diciembre de 1986 (R. 7.211 y 7.479 ) ya ha manifestado su parecer favorable a la conservación de las actuaciones correspondientes a quienes superaron las pruebas de idoneidad, entre otras razones, por las consecuencias perniciosas de orden práctico que ello acarrearía. La nulidad pretendida en modo alguno podría ser examinada sin que se procediera previamente al emplazamiento de aquéllos $-y$ de cuantos obtuvieron al menos tres puntuaciones de seis o superior- por estar identificados con sus respectivos 
domicilios en las actuaciones sustanciadas ante el Tribunal a quo (folios 75 a 79 y 185 a 189), lo que exigiría la previa devolución de las mismas a éste para subsanar los emplazamientos omitidos $y$ nueva tramitación y fallo de las cuestiones planteadas por parte de la Audiencia Territorial. Si a esto se añade que no existe limitación en cuanto al número de aspirantes que pueden ser propuestos para el acceso a las categorías de profesor titular y que difícilmente pueden seguirse perjuicios para los recurrentes -en caso de que fueran declarados idóneos- respecto a su futuro profesional a la hora de optar, junto a los ya declarados idóneos, a cualquier otra escala profesional -argumento esgrimido en esta alzada-, pues la provisión de vacantes en el Cuerpo de Catedráticos de Universidad tienen lugar por concurso de méritos en la forma que previene el artículo 38 de la Ley de Reforma Universitaria, puede llegarse a la conclusión que la estricta observancia del principio de igualdad -igualdad de baremo- en el caso de autos jugaria, más que en interés de los recurrentes, en perjuicio ajeno. En tales circunstancias la estimación de la pretensión que se examina resultaría contraria a la equidad, como acertadamente pone de relieve la sentencia apelada, equidad que, si constituye un límite al ejercicio de la potestad de anulación (art. 112 de la Ley de Procedimiento Administrativo), debe templar también en vía de recurso administrativo el rigor de una petición que, si se hubiera acogido en su totalidad -lo fue en parte al disponer la Administración que se evaluaran de nuevo los méritos de los recurrentes previa fijación de nuevos criterios de valoración- podría haber puesto en entredicho el principio de seguridad jurídica garantizado en el artículo 9.3 de la Constitución.» (Sentencia de 20 de enero de 1987. Sala 5. ${ }^{a}$ Fernández Díaz. Ar. 258.)

\section{SANCIONES}

\section{Expediente disciplinario. Propuesta de incoación a Secretario} de Administración local

"Que en el presente recurso contencioso-administrativo interpuesto por el cauce de la Ley 62/1978, de 26 de diciembre, se impugna por el hoy apelante, por presunta vulneración de derechos constitucionales especialmente protegidos, determinados acuerdos plenarios del Ayuntamiento de Cassá de la Selva, por los que, en el primero de ellos, se disponía incoar expedientes disciplinarios contra los funcionarios administrativos de dicho Ayuntamiento, lo que no afectaba al precitado apelante, dada su cualidad de 
Secretario del mencionado Ayuntamiento, extremo que determinaba que respecto a él, por el Alcalde se propusiera a la Comisión Permanente que se dirigiera a la Dirección General de Administración Local para que, por ésta, se incoara, obviamente si lo estimaba procedente, expediente disciplinario contra el hoy apelante, no constando en el expediente administrativo si la proposición de la Alcaldía determinó alguna actuación posterior en el sentido expuesto; en los otros dos acuerdos igualmente impugnados, se suprimian determinadas retribuciones complementarias de los funcionarios administrativos y del Secretario de la Corporación y se disponía, por último, una reestructuración del horario de las oficinas municipales, alegándose por el apelante que los aludidos actos administrativos infringen los derechos constitucionales declarados en los artículos 14 -principio de igualdad-, 24 -presunción de inocencia-, 25 -principio de legalidad en materia de sanciones- y 29 -derecho de petición-, presuntas vulneraciones que son rechazadas en la sentencia ahora apelada, al desestimar la pretensión impugnatoria del hoy apelante. (Sentencia de 20 de enero de 1987. Sala 3. ${ }^{a}$ Ruiz-Jarabo Ferrán. Ar. 19.)

2. Derecho administrativo sancionador. Sanción de separación del servicio de la Guardia Civil. Falta de formulación de pliego de cargos. Omisión del trámite de audiencia

"Las omisiones de estos trámites esenciales en todo expediente sancionador infringen manifiestamente lo establecido en los artículos 24 y 25 de la Constitución en cuanto el sancionado ignora la acusación formulada contra él $y$, al mismo tiempo, queda privado de cualquier posibilidad de defensa, conculcándose la presunción de inocencia. Es cierto que el artículo 24 de la Constitución contiene una expresa referencia a los procedimientos judiciales al establecer el derecho de todo ciudadano a obtener la tutela efectiva de los jueces y tribunales, pero este precepto ha sido interpretado tanto por esta Sala con reiteración como también reiteradamente por el Tribunal Constitucional en el sentido de que los principios esenciales reflejados en el artículo 24 de la Constitución en materia de procedimiento han de ser aplicados a la actividad sancionadora de la Administración en la medida neçesaria para reservar los valores esenciales que se encuentran en base del precepto y en la seguridad jurídica que garantiza el artículo 9 -de la Constitución-, debiéndose de tener en cuenta además que los principios inspiradores del orden penal son de aplicación, con ciertos matices, al Derecho administrativo sancionador, dado que ambos son manifes- 
taciones del ordenamiento punitivo del Estado -sentencia de 8 de junio de 1981-. La omisión de los trámites esenciales antes dichos por la autoridad militar no puede subsanarse por el hecho de haber recibido declaración al sancionado, a quien posteriormente se le indicó que, contra el acuerdo que le expulsó del Cuerpo, procedía recurso de alzada ante el Consejo Supremo de Justicia Militar, ya que el segundo es un acto posterior a la resolución sancionadora, que ya era inconstitucional, y la declaración del sancionado no puede sustituir en ningún caso a la formulación de un pliego de cargos a su notificación al expedientado ni a la posterior puesta de manifiesto del expediente, todo ello omitido en el presente caso, como resalta el Ministerio Fiscal, interpuesto por el Letrado del Estado.) (Sentencia de 20 de enero de 1987. Sala 3. ${ }^{a}$ Martín Herrero. Ar. 20.)

3. Principio de legalidad. No cabe la imposición de sanciones sin norma habilitante con rango de Ley que las tipifique y castigue. Infracción administrativa derivada de la normativa especial sobre horarios comerciales establecida en un Decreto del Consell de Generalitat Valenciana

«El Tribunal Constitucional ha reconocido que nuestra primera Ley configura una potestad sancionadora en manos de la Administración, aun cuando con las necesarias cautelas para preservar y garantizar los derechos de los ciudadanos. Entre los límites que tal potestad encuentra en la propia Constitución, ha de situarse en lugar preferente el de la legalidad, según la cual la cobertura de aquélla ha de estar constituida necesariamente por una norma de rango legal, como consecuencia de su carácter excepcional -sentencias 77/1983, de 3 de octubre; 25/1984, de 23 de febrero-. En el mismo sentido, esta Sala Tercera ha insistido en que la atribución a las Administraciones públicas de la potestad para sancionar ha de realizarse a través de la Ley formal, y con este significado estricto ha de ser entendida la palabra "legislación" utilizada en el tantas veces invocado artículo 25 del texto constitucional. Ahora bien, no sólo la investidura o habilitación está sometida al principio de la legalidad, sino también la tipificación de las infracciones, así como la dẹterminación de la sanción correspondiente -sentencia de 10 de noviembre de 1986-. Es suficiente en tal aspecto una Ley ordinaria, mientras que el ius puniendi exige para su regulación y, sobre todo, para la imposición de penas privativas de libertad una norma con rango de orgánica, conforme ha explicado recientemente el Tribunal Constitucional de cambios y 
los llamados "delitos monetarios" -sentencias 140 y 196, de 11 de noviembre de 1986-..) (Sentencia de 20 de enero de 1987. Sala 3. Mendizábal Allende. Ar. 203.)

4. Actividad administrativa sancionadora. Decreto $37 / 1986$ del Gobierno de la Junta de Extremadura por el que se declara manifiestamente mejorable la finca "Valero». Indefensión por omisión del trámite de audiencia a los interesados

«Desde el momento que el Tribunal Constitucional declaró, en su sentencia de 8 de junio de 1981 (R. Const. 18), que "los principios esenciales reflejados en el artículo 24 de la Constitución Española en materia de procedimiento han de ser aplicables a la actividad sancionadora de la Administración en la medida necesaria para preservar los valores esenciales que se encuentran en la base del precepto y la seguridad jurídica que garantiza al artículo $9 .^{\circ}$ ", resulta conveniente precisar también si el Decreto de la Junta de Extremadura impugnado participa de la naturaleza de actividad administrativa "sancionadora" a la que sería aplicable el artículo 24 de la Constitución en virtud de la doctrina expuesta. $Y$ en este punto, es forzoso señalar que así como genéricamente el instituto de la expropiación forzosa no implica sanción de ninguna especie al expropiado, cuya privación del dominio no trae causa de ningún ilícito a él impugnable, sino a la demanda de un interés colectivo, en los casos de la expropiación del uso de un predio rústico y su arrendamiento forzoso, por aplicación de la Ley 34/1979, de 16 de noviembre, sobre fincas manifiestamente mejorables, tal carácter sancionador es evidente, ya que la privación coactiva del dominio útil se genera tras la valoración de una conducta del propietario donde se aprecia el incumplimiento del plan de explotación y mejora marcado por la Administración, con quebranto del interés social que representa la necesidad de aquella mejora. De esta forma, no cabe duda que el procedimiento administrativo seguido hasta llegar a la expropiación del uso y arrendamiento forzoso de la finca "Valero", en el término municipal de Torrejón el Rubio (Cáceres) ha debido producirse con acatamiento y respeto a las garantías jurídicas, predominantemente formales, que consagra el artículo 24 de la Constitución, lo que, por ende, debe constituir la temática principal de esta alzada. De lo recogido en éste y en el anterior fundamento se desprende que han existido dos fases en la tramitación del expediente, una, extensa, que se refiere a la declaración de finca manifiestamente mejorable a los fines del artículo $5 .^{\circ}$ de la Ley $34 / 1979$, es decir, señalamiento, aprọbación, ejecución y comprobación del plan de explotación y mejora del 
predio, y otra, breve, que comprende el proceso de elaboración del Decreto de declaración de finca manifiestamente mejorable a los fines del artículo $6 .^{\circ}$ de la propia Ley. La confusa frontera entre ambas se encuentra en la comunicación que lleva fecha de registro de salida de 2 de mayo de 1986 (número 981), que la recurrente acompañó a su escrito de iniciación de este pleito. En ella se dice "que estando en curso... de elevación de propuesta de calificación como finca manifiestamente mejorable a efecto de lo dispuesto en el artículo $6 .^{\circ}$ de la Ley $34 / 1979$, de 16 de noviembre, ..." ; y añade que "... se le cita para que en el plazo de veinte días... presente... las alegaciones que estime oportunas conformes a Derecho". Resulta así que de una parte, claramente indica la iniciación de la fase del Decreto expropiatorio a que se refiere el artículo $6 .^{\circ}$; mas, de otra, no concede el trámite de "audiencia de los interesados" a que se refiere el propio artículo, sino el de alegaciones conforme a Derecho. Y no cabe confundir uno y otro, porque al hablar la Ley 34/1979 de "audiencia de los interesados", es incuestionable que se está refiriendo al especial trámite que, bajo la misma denominación, se contiene en el artículo 91 de la Ley de Procedimiento Administrativo. Con arreglo a éste, la "audiencia" implica necesariamente: a) la puesta de manifiesto del expediente al interesado; $b$ ) el derecho a presentar documentos y justificantes, y $c$ la formulación de alegaciones; todo ello dentro de un plazo no inferior a diez días ni superior a quince, y tan pronto como el expediente esté concluso, únicamente a falta de la propuesta de resolución y de, en su caso, el informe del servicio jurídico del órgano...» (Sentencia de

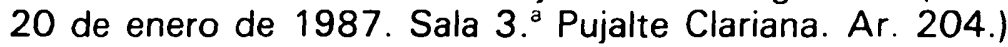

5. Sanciones administrativas en materia de contrabando. Importación de mercancías sin presentarlas para su despacho en las oficinas aduaneras. Hechos ocurridos bajo el imperio del texto refundido de 1964. Normativa vigente Ley Orgánica 7/1982. Derecho transitorio

"La faceta sustantiva, única relevante para el presente proceso, es contemplada en la norma transitoria siguiente, en donde se consigna que tendrán efectos retroactivos los preceptos de la nueva Ley en cuanto favorezcan a los responsables de los actos constitutivos de contrabando, en los términos establecidos en el artículo 24 del Código penal. Tal retroactividad incide ante todo en la delimitación entre delito y falta, degradando, así, la calificación de los supuestos incriminados a simple contravención administrativa... 
Ahora bien, la sanción principal de carácter pecuniario aparece graduada con distinto criterio en las leyes antigua y nueva. Según el texto refundido de 1964, las infracciones de menor y de mayor cuantía, como fueron calificadas éstas, habían de ser castigadas con multas no inferiores al duplo ni superiores al cuádruplo o entre este montante y seis veces más, respectivamente, de los géneros o efectos objeto de la contravención (art. 30.2. ${ }^{a}$ y 3. ${ }^{\text {\%) }}$. La vigente Ley Orgánica $7 / 1982$ fija los topes mínimo y máximo con un tope menos amplio, entre la mitad y el duplo (art. 12). En tal sentido, es sin duda "más benigna" y en suma favorable al inculpado, por lo que resulta obligado dotarla de eficacia retroactiva respecto de los actos administrativos enjuiciados en este proceso. El juego conjunto de los artículos 61 y 63 del Código penal, supletoriamente, como aplicable según se indica en nuestra sentencia de 6 de octubre de 1986, nos lleva a considerar adecuado en este caso el grado mínimo de la multa... Por otra parte, los artículos 27 y 31 del texto refundido de 1964 establecían la sanción accesoria de comiso de géneros, efectos e instrumentos en los supuestos de aprehensión y como sustitutoria en los demás de la condena al pago del valor equivalente. Esta última no aparece recogida en la Ley Orgánica $7 / 1982$ y esta volatilización por obra del principio de legalidad actuante, con todo rigor, tanto para el ius puniendi, como para la potestad sancionadora de las Administraciones Públicas (art. 25 de la Constitución), significa que no cabe imponer tal gravamen adicional y que ello, a su vez, opera retroactivamente, determinando aquí también la nulidad parcial sobrevenida de actos administrativos inicialmente correctos.) (Sentencia de 11 de febrero de 1987. Sala 3. ${ }^{a}$ Mendizábal Allende. Ar. 537.)

\section{URBANISMO}

1. Planeamiento. Necesidad de usar el trámite de información pública respecto de las rectificaciones introducidas en el acto de suspensión de la aprobación definitiva. Carácter normativo de los Planes. Importancia de la participación ciudadana en su elaboración

Considerandos de la sentencia apelada que se aceptan:

"Que como se ha puesto de manifiesto, el punto neurálgico de la discusión en este proceso radica en la necesidad o no de usar el trámite de publicación o información al público respecto de las 
rectificaciones o deficiencias que fueron introducidas en el acto de suspensión de la aprobación definitiva, con relación a la Revisión del Plan discutido... teniendo en cuenta que cuando las deficiencias señaladas sean de una entidad o importancia que verdaderamente sean sustanciales, en este caso, según lo determinado por el artículo 132.3.b) del Reglamento de Planeamiento, en consonancia con el artículo 41 del TR de la Ley del Suelo, debe procederse a una nueva información pública, elevándose por el Ayuntamiento finalmente, previo acuerdo del mismo, a la aprobación definitiva, porque de este modo se garantiza suficientemente los derechos de los administrados, mientras que, en caso contrario, no sucede asi, conculcándose el espíritu y finalidad pretendida por el legislador, y por ello es evidente que al constar las deficiencias o prescripciones introducidas por la Comisión de Urbanismo de Barcelona, en el acto reseñado, suspendiendo la aprobación definitiva bajo los epígrafes llamados "Generales", "Normativa" y "Corrección de errores materiales", del apartado contenido en el epigrafe "Normativa", se deducen con claridad, deficiencias o rectificaciones que encajan plenamente en el concepto de sustanciales respecto de las directrices del instrumento de planeamiento...»

\section{Considerandos del Tribunal Supremo:}

«... La exigencia de un determinado procedimiento para dictar Reglamentos es un requisito formal de especial rigor, de suerte que su infracción provoca la nulidad de pleno derecho, doctrina ésta aplicable al supuesto litigioso dada la naturaleza normativa de los Planes.

... Los Planes de Ordenación urbana constituyen una decisión capital que condiciona el futuro desenvolvimiento de la comunidad, afectando de forma trascendental a la calidad de vida de los ciudadanos. De ahí la importancia de su participación en la elaboración de los Planes; con ella reciben éstos la necesaria legitimación democrática, $y$, justamente por ello, se eliminan o atenúan las tensiones a la hora de su ejecución.» (Sentencia de 1 de diciembre de 1986. Sala 4. ${ }^{a}$ Delgado Barrio. Ar. 415).

2. Licencia municipal de apertura de establecimiento en suelo no urbanizable. Silencio positivo. Actividades molestas, peligrosas o insalubres

Considerandos de la sentencia apelada que se aceptan:

"Que, sin embargo, no puede todavía proclamarse la existencia de la licencia, a la vista de que, con anterioridad $y$ a instancia del 
coadyuvante, se seguía en el mismo Ayuntamiento el expediente 185/1983, con el objeto de verificar si la industria del bar en cuestión podía ser autorizada 0 , por el contrario, clausurada con arreglo al Reglamento de Actividades Molestas, Insalubres o Peligrosas, expediente que el Ayuntamiento no tramitó conforme a lo dispuesto en los artículos 29 y siguientes del Reglamento de 30 de noviembre de 1961, sino que lo decidió, llegando a la clausura, con fundamento exclusivamente urbanístico, incumpliendo el artículo 22 del Reglamento de Servicios, que deslinda perfectamente las licencias urbanísticas referentes a un establecimiento de características determinadas, en las cuales no se concederá el permiso de obras sin licencia de apertura, si fuere procedente, y como en el caso de autos se habia denunciado que la actividad era molesta, es evidente que sin que se obtenga la licencia de apertura por los trámites del Reglamento de Actividades no puede prosperar ninguna licencia urbanística de apertura y tampoco la que, por silencio positivo, prevé el Reglamento de servicios en su artículo 9 ya citado.» (Sentencia de 19 de enero de 1987. Sala 4. Martín Martín. Ar. 429).

3. La incorporación a la vía pública del terreno que exceda de la edificación de un solar como consecuencia del retranqueo impuesto en virtud de nuevas alineaciones aprobadas en un Plan urbanístico. Cesión gratuita o indemnización

«... d) Que el problema litigioso consistente en determinar si la incorporación a la vía pública del terreno en cuestión debe ser objeto de cesión gratuita o indemnizados en su justo valor, ha sido resuelto por esta Sala en sentencia de 17 de febrero de 1979, que, recogiendo la doctrina que cita, reitera la doctrina de la cesión gratuita de dichos terrenos, tanto en las nuevas urbanizaciones como en las de reforma interior, con fundamento en el principio de compensación de los beneficios que el propietario obtiene a consecuencia de la acción urbanizadora, y tal doctrina es de inexcusable aplicación al caso de autos, ya que el propietario demandante, que por su propia iniciativa y voluntad ha construido el edificio, obtiene con la nueva lineación impuesta en un Plan vigente, aparte del beneficio general que ello supone para su propiedad, el concreto y acreditado de una mayor altura de edificación que debe tener su adecuada compensación con la cesión gratuita de este terreno excedente al órgano urbanístico municipal que llevó a cabo la urbanización, sentencia de 2 de abril de 1981 (R. 1.809). e) Que la cesión obligatoria de terrenos a fines 
urbanísticos no significa que la carga económica que conlleva deba ser exclusivamente soportada por el propietario a quien se impone, pues el principio de igualdad que la apelante invoca al amparo del artículo 3.2.b) de la Ley del Suelo obliga a equilibrar entre todos los afectados por una actuación urbanística los respectivos beneficios y cargas que cada uno de ellos recibe, $y$, en consecuencia, procede examinar los efectos que la aplicación de dicho principio tiene en el caso de autos $y$ en tal aspecto debe destacarse que no parece existir un sacrificio superior en la propiedad que cede una porción de terreno inferior a la cedida por la otra propiedad implicada en la apertura de la nueva calle; pero aunque así no fuese, y para ello tendrían que probarse los beneficios que de dichas cesiones obtienen los referidos propietarios, e incluso otros distintos que pueden obtener beneficios sin necesidad de soportar carga alguna, la producción de un desproporcionado sacrificio para el cedente del terreno no le libera de su obligación de cederlo, sino que únicamente le concede el derecho a la compensación económica que corresponda -sentencia de 15 de junio de 1983 (R. 3.529).» (Sentencia de 10 de febrero de 1987. Sala 5. ${ }^{a}$ Fuentes Lojo. Ar. 581).

4. Licencia de obras. Denegación de licencia de construcción por haber recaído con posterioridad a la solicitud aprobación inicial de Catálogo de Patrimonio Histórico-Artístico. Naturaleza de los Catálogos

«Solicitada licencia de edificación al Ayuntamiento de Barcelona, con fecha 23 de abril de 1976, se denegó por la Corporación Municipal Metropolitana en vía de subrogación, por haber recaído con posterioridad aprobación inicial del Catálogo del Patrimonio Artístico de la Ciudad en el que se incluía el solar donde se interesaba la licencia, acto que fue confirmado por la sentencia objeto de revisión. La fundamentación de la resolución judicial es que, según el artículo 27.3 de la Ley del Suelo, la aprobación de los Catálogos produce la suspensión de las licencias solicitadas y que se soliciten con posterioridad, dada la naturaleza del registro como medio informativo que forma parte integrante de la planificación, al que le resultan aplicables las normas sobre medidas cautelares durante el período de formación del Plan del artículo 27 de la Ley del Suelo, pese a no estar literalmente incluido en esta norma y a la interpretación antirrestrictiva de las limitaciones de la Propiedad, porque al ser el Catálogo uno de los documentos del Plan, ha de estar aprobado simultáneamente a éste, o de serlo separadamente, 
basta entonces que sea desarrollo del Plan precedente o de Ordenanzas de Defensa del Patrimonio, como ocurre en este caso en que las normas urbanísticas del Plan general preveían una primera etapa a través de un Plan Especial de protección del Patrimonio Artístico y de una Ordenanza y Catálogo correspondientes...) (Sentencia de 19 de febrero de 1987. Sala 3. ${ }^{a}$ Carretero Pérez. Ar. 663). 
REALA-1988, núm. 238. ALONSO IBAÑEZ, MARIA ROSARIO. RESEÑA DE SENTENCIAS DEL TRI...

REALA-1988, núm. 238. ALONSO IBAÑEZ, MARIA ROSARIO. RESEÑA DE SENTENCIAS DEL TRI... 